\title{
"Candidatus Phlomobacter fragariae" Is the Prevalent Agent of Marginal Chlorosis of Strawberry in French Production Fields and Is Transmitted by the Planthopper Cixius wagneri (China)
}

\author{
Jean-Luc Danet, Xavier Foissac, Leyla Zreik, Pascal Salar, Eric Verdin, \\ Jean-Georges Nourrisseau, and Monique Garnier
}

\begin{abstract}
First, second, third, fourth, fifth, and seventh authors: Laboratoire de Biologie Cellulaire et Moléculaire, UMR Génomique, Développement et Pouvoir Pathogène, Institut de Biologie Végétale Moléculaire, INRA et Université Victor Ségalen Bordeaux 2, BP 81-33883, Villenave d'Ornon, Cedex-France; and sixth author: Unité Mixte de Recherche en Santé Végétale, Institut National de la Recherche Agronomique, 33883 , Villenave d'Ornon cedex, France.
\end{abstract}

Accepted for publication 24 December 2002.

\begin{abstract}
Danet, J.-L., Foissac, X., Zreik, L., Salar, P., Verdin, E., Nourrisseau, J.-G., and Garnier, M. 2003. "Candidatus Phlomobacter fragariae" is the prevalent agent of marginal chlorosis of strawberry in French production fields and is transmitted by the planthopper Cixius wagneri (China). Phytopathology 93:644-649.

Marginal chlorosis has affected strawberry production in France for about 15 years. A phloem-restricted uncultured bacterium, "Candidatus Phlomobacter fragariae," is associated with the disease. A large-scale survey for marginal chlorosis in French strawberry production fields and nurseries by polymerase chain reaction amplification of " $\mathrm{Ca}$. $\mathrm{P}$.

not always induced by " $\mathrm{Ca}$. P. fragariae" and that the stolbur phytoplasma could induce identical symptoms. " $\mathrm{Ca}$. P. fragariae" was found to be predominant in strawberry production fields, whereas the stolbur phytoplasma was predominantly detected in nurseries. Two transmission periods of the disease, one in spring and the other from late summer to early fall, were evident. Cixius wagneri planthoppers captured on infected strawberry plants were demonstrated to be efficient vectors of " $\mathrm{Ca}$. P. fragariae." The involvement in natural disease spread of the whitefly Trialeurodes vaporariorum, previously shown to acquire and multiply "Ca. P. fragariae" under greenhouse conditions, remains uncertain.
\end{abstract} fragariae" $16 \mathrm{~S}$ rDNA revealed that symptoms of marginal chlorosis were
Additional keyword: proteobacteria.
Phloem-restricted and unculturable pathogens such as phytoplasmas and bacterialike organisms have been reported worldwide as being associated with several diseases of strawberry plants (21). Phytoplasmas form an important group of plant pathogens now phylogenetically characterized by $16 \mathrm{~S}$ rDNA sequences into 14 to 20 taxonomic groups in the class Mollicutes $(19,27)$. Thirteen different phytoplasmas are known to infect strawberry plant. Phytoplasmas belonging to six subgroups within the aster yellows group (16SrI) have been reported to induce strawberry multiplier-like, strawberry stunting diseases in Florida, strawberry green petal and phyllody in North America and Europe, and more recently, strawberry phylloid fruit in West Virginia $(2,11,12,14$, 16). In New Zealand, the Phormium yellow leaf phytoplasma, closely related to "Candidatus Phytoplasma australiense" (16SrXII-B group) (24) was found to be associated with strawberry lethal yellows (1), whereas in France, the stolbur phytoplasma (16SrXII-B subgroup) was reported to occasionally infect strawberry plants (4). Five other phytoplasmas belonging to subgroups 16SrIII-B, 16SrIII-K, 16SrIV-A, 16SrIV-B, and 16SrXIII$\mathrm{B}$ were also found to induce stunting, chlorosis, and flower abnormalities $(11,13,15-18)$. In Australia, in addition to a phytoplasma not phylogenetically characterized, a walled bacteriumlike organism was observed in diseased strawberry (11). Remission of symptoms was obtained after penicillin treatment and thus confirmed the bacterial nature of the agent. In France, strawberry production has been severely affected by marginal chlorosis for

Corresponding author: X. Foissac; E-mail address: foissac@bordeaux.inra.fr

Publication no. P-2003-0325-01R

(c) 2003 The American Phytopathological Society more than 15 years. A bacteriumlike organism was found in the sieve elements of affected plants (23). Because this bacterium has resisted in vitro cultivation, $16 \mathrm{~S}$ rDNA was cloned and sequenced and the bacterium was shown to be a candidate as a new genus and species to be included in the gamma subdivision of Proteobacteria and was named "Candidatus Phlomobacter fragariae" (30). For field diagnosis, a polymerase chain reaction (PCR) test was developed to specifically amplify part of the " $\mathrm{Ca}$. P. fragariae" $16 \mathrm{~S}$ rDNA from affected strawberry plants (30). Because all known phloem-restricted prokaryotes are transmitted by homopteran insects (leafhopper, planthoppers, or psyllids), a search for "Ca. P. fragariae"-infected homopteran insects was carried out. Because the 16S PCR test resulted in cross-reactions with insect endogenous proteobacteria, a new PCR based on the amplification of a less conserved gene (spoT) was developed (3). spoT amplification followed by restriction fragment length polymorphism (RFLP) analyses was used to detect " $\mathrm{Ca}$. P. fragariae" in fieldcollected homopteran insects. From 1994 to 2000, no insect was found infected with the proteobacterium, whereas whiteflies proliferating on infected strawberry plants in the greenhouse acquired and multiplied the bacterium (3).

In France, strawberry production fields are located in the southwestern part of the country and most nurseries are located in the Loire Valley, in the northwest. After a first propagation of in vitro stock plants, nurseries establish mother plants in the spring for harvest in the fall and summer planting in production fields after storage at $0^{\circ} \mathrm{C}$ for several months. Typical marginal chlorosis symptoms can be observed in the fall in nurseries, affecting a small percentage of the plants. Diseased plants are eradicated by nursery workers before runners are harvested. Production fields are generally established in early summer under small or large 
plastic tunnels, and remain in production for 1 to 3 years. Marginal chlorosis has been reported in strawberry production fields with an incidence of a few plants to nearly $100 \%$ of plants in some production tunnels. Results are presented from surveys undertaken from 1996 on the incidence and dissemination of marginal chlorosis of strawberry in nurseries and production fields. This study demonstrates that the disease can be induced by two different phloem-restricted bacterial pathogens with different geographical distribution. It also demonstrates that " $C a$. P. fragariae" is efficiently transmitted by the planthopper Cixius wagneri (China) whose populations are highly variable from year to year. The involvement of the whitefly Trialeurodes vaporariorum (Westwood) in natural spread remains uncertain, even though $T$. vaporariorum was previously shown to acquire and multiply " $\mathrm{Ca}$. P. fragariae" under greenhouse conditions.

\section{MATERIALS AND METHODS}

Plant material. Healthy strawberry (Fragaria $\times$ ananassa Duch) plants were produced by meristem tip culture and in vitro propagation. Strawberry plants infected with " $\mathrm{Ca}$. P. fragariae" were taken from strawberry fields in 1995 and maintained as reference plants in a greenhouse kept at $25^{\circ} \mathrm{C}$ during the day and $20^{\circ} \mathrm{C}$ at night; they were continually propagated from infected runners. Symptomless and marginal chlorosis-affected plants were collected from various areas in France. Healthy periwinkle (Catharanthus roseus L.) plants were produced from seeds.

Insects. In 2001 (April to October), insects were collected from strawberry growing areas with a D-Vac aspirator. They were recovered with a mouth aspirator, separated according to species, and either tested immediately or kept at $-25^{\circ} \mathrm{C}$ for later testing. Insects were identified using taxonomy handbooks for planthoppers, leafhoppers $(9,25,26)$, and whiteflies (20). Identification of Cixius wagneri was reviewed by $\mathrm{T}$. Bourgoin (homopteran expert from the French National Museum of Natural History).

Extraction of DNA from plants and insects. Nucleic acids were extracted from strawberry plants as described by Gawel and Jarret (8). DNA was extracted from individual insects or batches of 5 to 10 insects according to their size and to the number captured using the same procedure.

PCR amplification of " $\boldsymbol{C a}$. P. fragariae." Primers Fra4 (5'CTCCTCTGTCTCTAAAGG-3') and Fra5 (5'-AGCAATTGACATTAGCGA-3') from the 16S rDNA sequence of " $C a$. P. fragariae" were used for amplification of DNA extracted from strawberry plants under the following conditions: 35 cycles of $1 \mathrm{~min}$ at $92^{\circ} \mathrm{C}$, $1 \mathrm{~min}$ at $52^{\circ} \mathrm{C}$, and $1 \mathrm{~min}$ at $72^{\circ} \mathrm{C}$. The amplified DNA was visualized by electrophoresis on $1 \%$ agarose gels by standard procedures. spoT PCR-RFLP was carried out as described previously (3). The spoT amplicon obtained from Cixius wagneri DNA extracts was directly sequenced by automated fluorescent sequencing and compared with the previously published " $\mathrm{Ca}$. $\mathrm{P}$. fragariae" spoT amplicon (3) (GenBank Accession No. AF191253).

Detection of the stolbur and aster yellows phytoplasmas. The stolbur phytoplasma was detected by immunofluorescence as described previously (5) or by PCR according to Maixner et al. (22). Aster yellows-type phytoplasmas were detected by amplifying part of the $16 \mathrm{~S}$ and $16 \mathrm{~S}-23 \mathrm{~S}$ spacer regions using P1 and AYint primers (28).

Natural transmission assessments. In an experiment repeated for 3 years (1994 to 1996), 50 potted healthy strawberry plants (cv. Elsanta) and 50 healthy periwinkle plants (cv. Cooler) were introduced into a strawberry production tunnel in which high incidence of marginal chlorosis had been observed the previous year. They were replaced every 15 days from 1 April to 15 October with 50 new strawberry and periwinkle plants. Plants from each batch (i.e., 1,300 plants) were kept in an insect-proof greenhouse for at least 6 months before being examined for symptoms and being tested for " $\mathrm{Ca}$. P. fragariae" by PCR.
In 1998,200 pots of healthy strawberry plants and 200 pots of healthy periwinkle plants were exposed next to a tunnel from April to October and then kept and tested as described previously. Finally, in 1999 to 2000, batches of 84 healthy strawberry plants were exposed throughout the growing season for 5-week periods in a tunnel with an annual plantation established in July and removed in May.

Transmission of “Ca. P. fragariae.” In May 2001, adult planthoppers Cixius wagneri were taken from annual strawberry plantings displaying about $10 \%$ marginal chlorosis and caged until death on healthy strawberry plants. DNA was then extracted from the dead planthoppers individually and tested by spoT-PCR-RFLP for the presence of " $\mathrm{Ca}$. P. fragariae." The plants used in the transmission experiments were treated with insecticide and kept in an insect-proof greenhouse.

Transmission experiments with whiteflies. In spring 1999, about 360 healthy strawberry plants were planted in three large tunnels made of insect-proof nylon screen. In tunnels A and B, 38 " $C a$. P. fragariae"-infected strawberry plants were planted alternately with healthy strawberry plants. In February to March of each year, all tunnels were treated with insecticide. The infected strawberry plants that died during the growing season were replaced in order to maintain good inoculum levels. Healthy tobacco plants carrying whiteflies ( $T$. vaporariorum) were introduced twice during three consecutive springs to tunnel A. Tobacco plants were not watered so the insects would move to strawberry plants. In October 2000 and 2001, all strawberry plants were examined for symptoms and tested for " $\mathrm{Ca}$. P. fragariae" infection by $16 \mathrm{~S}$ rDNA PCR.

\section{RESULTS}

Survey of French nurseries and production fields for marginal chlorosis and " $\mathbf{C a}$. P. fragariae." More than 500 strawberry plants were collected between November 1996 and November 2001 from 30 different strawberry production fields and 23 different nurseries. Most plants showed characteristic marginal chlorosis symptoms (23), but some had atypical symptoms such as stunting or interveinal chlorosis. Strawberry fields located in southwestern France (Dordogne, Lot, and Lot et Garonne) accounted for half of the French strawberry fruit production, the other half being produced in southeast (Gard) and western France

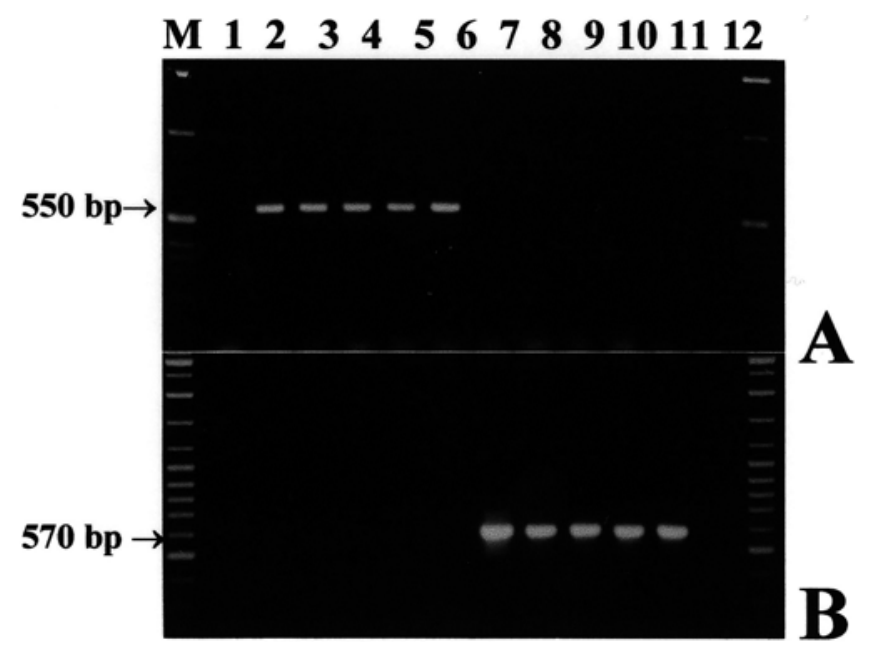

Fig. 1. Agarose gel electrophoresis of amplification products obtained with "Candidatus Phlomobacter fragariae" primers A, Fra4/Fra5 and B, fStol/rStol on DNA extracted from symptomless strawberry plants (lanes 1 and 12) and from 10 strawberry plants showing marginal chlorosis symptoms (lanes 2 to 11). Lanes 1 to 6 correspond to plants collected from production fields, and lanes 7 to 12 correspond to plants collected from nurseries. M, molecular size markers: A, 1-kb (Invitrogen, Cergy Pontoise, France) and B, 1-kb (MBI Fermentas, Vilnius, Lithuania). 
(Finistère, Loir et Cher, and Loire Atlantique). Nursery fields are located principally in western France (Loir et Cher, Maine et Loire, Sarthe, and Finistère) with only a few in southwestern France (Gironde, Landes, Lot, and Lot et Garonne). When tested by PCR with primers Fra4/Fra5 which are specific for " $\mathrm{Ca}$. P. fragariae" $16 \mathrm{~S}$ rDNA, 183 of the 260 symptomatic strawberry plants from the fruit production fields gave a positive reaction. Surprisingly, only 17 of the 247 nursery plants tested positive. We thus looked for other pathogens in the symptomatic nursery plants. Because phytoplasmas infect strawberry plants (21), we first looked for the presence of the stolbur phytoplasma, which we knew from previous work occasionally was present in strawberry plants in southwestern France (4). An immunofluorescence reaction with MA 2A10, specific for the stolbur phytoplasma (5), gave a strong positive reaction with nursery strawberry plants showing marginal chlorosis. We then retested all our strawberry DNAs with primers $\mathrm{fStol} / \mathrm{rStol}$ (22), which are specific for the stolbur phytoplasma $16 \mathrm{~S}$ rDNA. A total of 126 nursery plants and 10 plants from the production fields gave positive reactions. As an example, Figure 1 (lanes 2 to 11) shows the results of PCR amplification with primers Fra4/Fra5 (Fig. 1A) and primers fStol/rStol (Fig. 1B) on DNA extracted from 10 strawberry plants showing marginal chlorosis symptoms. Samples coming from strawberry production fields (Fig. 1, lanes 2 to 6) were positive for the 550-bp PCR product indicating " $\mathrm{Ca}$. P. fragariae" infection, whereas the stolbur phytoplasma 16S rDNA 570-bp amplicon was obtained from the nursery samples (Fig. 1, lanes 7 to 11). No amplification was obtained with symptomless field or nursery strawberry plants (Fig. 1, lanes 1 and 12, respectively). These results showed that " $C a$. P. fragariae" is predominant in strawberry production fields in western France (Fig. 2, left), whereas the stolbur phytoplasma is found essentially on nursery plants (Fig. 2, right). When characteristic symptoms were present, $80.6 \%$ of the strawberry plants from production fields were positive for " $\mathrm{Ca}$. $\mathrm{P}$. fragariae" and $4.2 \%$ were positive for the stolbur phytoplasma, whereas in nurseries, $67.3 \%$ of the plants were positive for stolbur phytoplasma and $8 \%$ of the plants were positive for " $\mathrm{Ca}$. $\mathrm{P}$. fragariae." In production fields, $18.6 \%$ of the plants with atypical symptoms tested positive for " $\mathrm{Ca}$. P. fragariae" and none were found infected by the stolbur phytoplasma, whereas in nurseries, $29.4 \%$ of such plants were positive for the stolbur phytoplasma and $4.7 \%$ were positive for " $\mathrm{Ca}$. P. fragariae." Five plants with petal virescence symptoms from a production field in Loir et Cher in 2000, were found infected with an aster yellows-type phytoplasma when tested with aster yellows specific PCR primers. Finistère and Loire Atlantique were the only two areas where no characteristic marginal chlorosis symptoms were observed, and neither pathogen was detected.

Evidence for natural transmission of “ $\mathrm{Ca}$. P. fragariae” by an aerial vector. Transmission experiments were performed to determine whether " $C a$. P. fragariae" was transmitted to strawberry plants in production tunnels by an aerial vector or entered tunnels as infected nursery plants. Of the 650 healthy strawberry plants exposed for 15-day periods during 1996 within a tunnel in which a high incidence of marginal chlorosis was observed the preceding year, only one plant developed characteristic symptoms. None of those exposed in 1995 and 1997 became symptomatic. When tested by PCR with primers Fra4/Fra5, the " $C a$. P. fragariae"-characteristic 550-bp band was obtained from the symptomatic strawberry plant that had been exposed from 15 to 30 May and showed symptoms on 1 October. None of the periwinkle bait plants exposed under the same conditions developed symptoms.

When plants were exposed for 7 months outside of the strawberry production tunnels, 20 of 200 strawberry plants developed symptoms and tested positive for " $\mathrm{Ca}$. P. fragariae." Some of the periwinkle plants also developed symptoms, but none gave a positive result with primers Fra5/Fra4. PCR with phytoplasma universal primers followed by RFLP showed the periwinkle symptoms to be the result of a phytoplasma infection (data not shown). In 1999 to 2000, batches of 84 strawberry plants were exposed within a production tunnel and renewed every 5 weeks from the August 1999 planting until termination of the experiment in June 2000. The results presented in Figure 3 indicate that there were

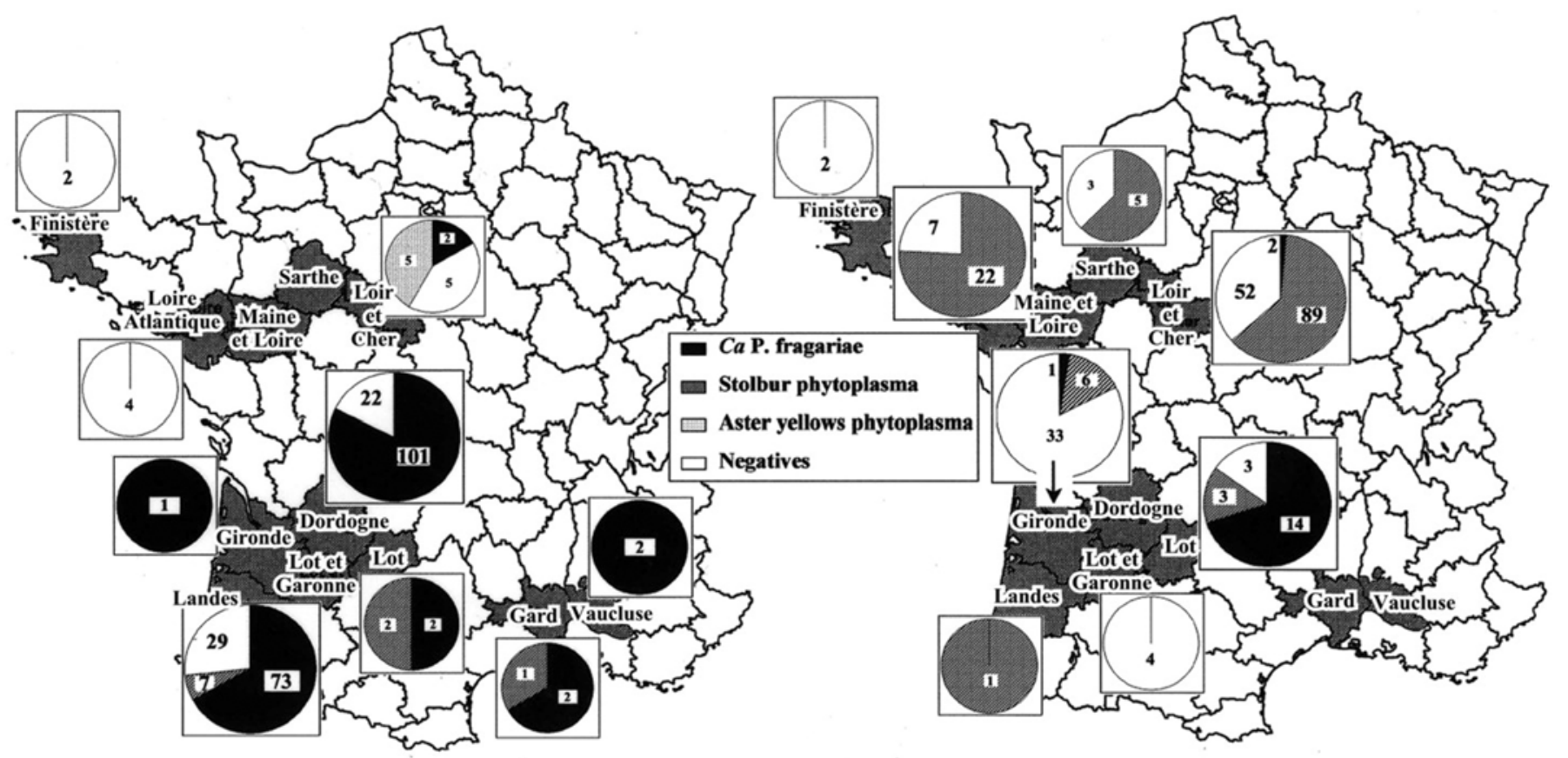

Strawberry production fields

1996-2001

Strawberry nurseries

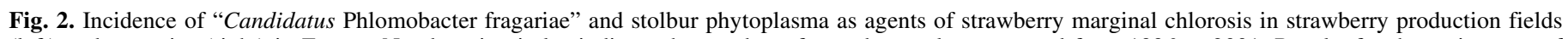

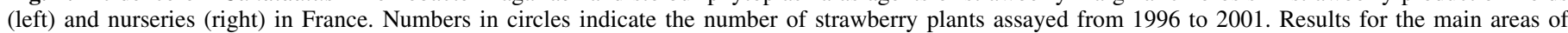
strawberry and plant production are represented in large circles. Small circles represent minor production areas for which only one or two farms were surveyed. 
two transmission periods, one between August and November and the other between the middle of April and the end of May.

Natural infection of Cixius wagneri by "Ca. P. fragariae" and experimental transmission. During the spring of 2001, a survey of the homopteran insects present in the strawberry production fields in which natural transmission was observed in 1999 to 2000 was carried out. Symptoms were observed on approximately $10 \%$ of the strawberry plants, including adult planthoppers, later identified as Cixius wagneri. Cixius wagneri insects feeding on diseased plants, previously shown to be infected with "Ca. P. fragariae," were captured in May and June 2001 and caged on healthy strawberry plants to determine transmission of the disease (Table 1). Throughout the transmission period, dead insects were collected and tested individually for " $\mathrm{Ca}$. P. fragariae" infection using spoT-PCR. As illustrated in Figure 4A and Table 1, the 895-bp spoT amplicon was obtained with the majority of insect DNA extracts. Results indicated that 71 to $87 \%$ of the planthoppers were infected with " $\mathrm{Ca}$. P. fragariae." Amplicon obtained from two insect DNA extracts were sequenced. Sequences were $99.8 \%$ identical (845 out of 847 nucleotides) to that of " $\mathrm{Ca}$. P. fragariae" established in 1997 from the bacterium in planta (3). In addition, 16 strawberry plants exhibited typical symptoms of marginal chlorosis after 2 months and 12 were positive by $16 \mathrm{~S}$ PCR as illustrated for some of the strawberry plants in Figure 4B. In September and October 2001, Cixius wagneri individuals were captured in two strawberry fields established in July in Dordogne and Lot et Garonne, respectively. Nineteen of the forty-six Cixius wagneri captured (41\%) were positive with the spoT-PCR but no marginal chlorosis symptoms were observed at that time; however, symptoms did develop in November and all the symptomatic plants were positive by PCR with primers Fra4/Fra5.

Evaluation of whiteflies $\mathrm{T}$. vaporariorum as a vector of " $\mathrm{Ca}$. P. fragariae." Previous study has shown that the whitefly $T$. vaporariorum acquired " $\mathrm{Ca}$. P. fragariae" (3). Whiteflies were grown in cages containing " $\mathrm{Ca}$. P. fragariae"-infected strawberry plants. We found that offspring were difficult to obtain from diseased plants and few insects were produced. Thus, healthy strawberry plants were introduced into the cages for at least 2 months. None of the introduced healthy plants developed marginal chlorosis.

In September 2001, about 2,000 whiteflies were captured in the strawberry fruit production farm from which infectious planthoppers had been found previously. Twenty batches of 50 whiteflies were tested by spoT-PCR followed by RFLP analyses. None

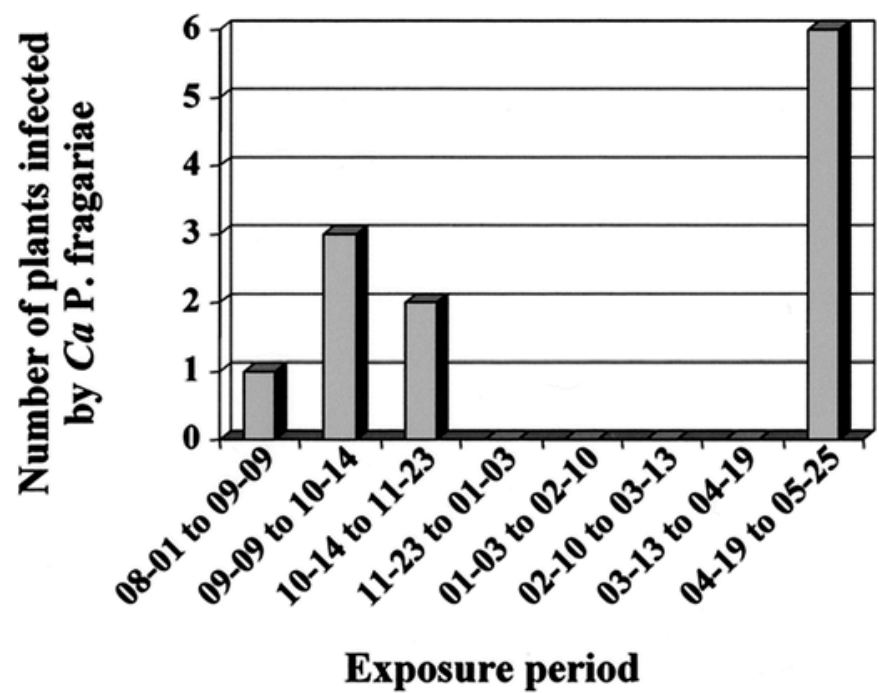

Fig. 3. Strawberry marginal chlorosis transmission period as determined by exposure of strawberry plants to natural contamination in annual plantings (1999 to 2000). of the whitefly batches gave the " $\mathrm{Ca}$. P. fragariae" characteristic RFLP pattern. The remaining 1,000 whiteflies were caged on five healthy strawberry plants. None of the plants developed marginal chlorosis symptoms up to 8 months after being exposed to whiteflies.

Finally, because the proportion of whiteflies able to acquire " $\mathrm{Ca}$. P. fragariae" in a production environment was expected to be very low since these insects are rarely observed on symptomatic strawberry plants, large-scale experiments were established in spring 1999 under three tunnels. Tunnels A and B contained both healthy and " $\mathrm{Ca}$. P. fragariae"-infected strawberry plants. In tunnel A, whiteflies had been delivered as described previously. Tunnel $\mathrm{C}$ contained only healthy strawberry plants. In October 2000, no symptoms were observed on the healthy strawberry plants of tunnels B and C. In tunnel A, 24 strawberry plants had marginal chlorosis symptoms and were infected with " $\mathrm{Ca}$. $\mathrm{P}$. fragariae" as determined by $16 \mathrm{~S}$ PCR. By October 2001, two additional strawberry plants in tunnel A were affected and eight additional strawberry plants in tunnel $\mathrm{B}$ were infected.

A search for homopteran insects in the tunnels was carried out in July and October 2001. In addition to the whiteflies present in tunnel A, Cixius wagneri adults were found in all tunnels. Of the 4,6 , and 26 planthoppers collected from tunnels A, B, and C, re-

TABLE 1. "Candidatus Phlomobacter fragariae" transmission using fieldcollected Cixius wagneri

\begin{tabular}{|c|c|c|c|c|c|}
\hline $\begin{array}{l}\text { Exp. } \\
\text { no. }\end{array}$ & $\begin{array}{l}\text { No. of } \\
\text { assayed } \\
\text { insects }\end{array}$ & $\begin{array}{c}\text { Transmission } \\
\text { period }^{\mathrm{a}}\end{array}$ & $\begin{array}{l}\text { No. of } \\
\text { PCR- } \\
\text { positive } \\
\text { insects }\end{array}$ & $\begin{array}{c}\text { No. of straw- } \\
\text { berry plants } \\
\text { exhibiting } \\
\text { symptoms }\end{array}$ & $\begin{array}{l}\text { No. of PCR- } \\
\text { positive } \\
\text { strawberry } \\
\text { plants }^{\text {b }}\end{array}$ \\
\hline I & 23 & 7 days (19 day & $20 / 23$ & $10 / 12$ & $9 / 12$ \\
\hline II & 14 & 6 days ( 14 days) & $10 / 14$ & $6 / 7$ & $3 / 7$ \\
\hline
\end{tabular}

a Time for which half of the insects were still alive; Numbers in parentheses indicate the time at which the last insect died.

b Tested by 16S (Fra4-Fra5) PCR amplification.

\section{$\begin{array}{lllllllllllll}M & 1 & 2 & 3 & 4 & 5 & 6 & 7 & 8 & 9 & 10 & 11\end{array}$}
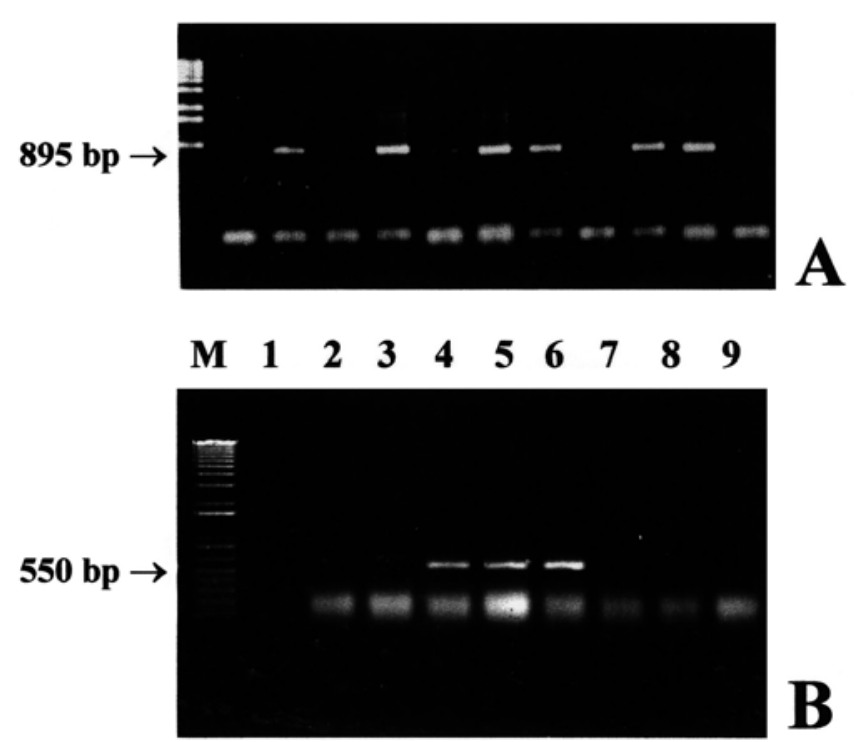

Fig. 4. A, spoT polymerase chain reaction (PCR) amplification using fieldcollected Cixius wagneri planthoppers and B, 16S PCR (Fra4/Fra5) amplification using strawberry plants exposed to field-collected Cixius wagneri. A, PCR amplification from water (lane 1), DNA extracted from "Candidatus Phlomobacter fragariae"-infected strawberry plant (lane 2), healthy strawberry plant (lane 3), and field-collected Cixius wagneri (lanes 4 to 11). B, PCR amplification from the DNA of healthy strawberry (lane 1), water (lane 2), and DNA from strawberry plants 2 months after exposure to batches of field-collected Cixius wagneri (lanes 3 to 9). M, 1-kb DNA ladder (Invitrogen, Cergy Pontoise, France). 
spectively, in July and October 2001, only 3 of them were infected by "Ca. P. fragariae" as determined by spoT-PCR and RFLP testing; one insect was collected in July 2001 from tunnel B and the other two were collected from the control tunnel (tunnel C).

\section{DISCUSSION}

Marginal chlorosis symptoms can be induced by two different pathogens, " $\mathrm{Ca}$. P. fragariae" and the stolbur phytoplasma; however, the symptoms are not distinguishable. Using specific detection methods developed for each of the two pathogens, we show that " $C a$. P. fragariae" predominated in the southwestern French strawberry production fields (Dordogne, Gironde, Lot et Garonne, and Lot), but also was present in the southeastern (Gard) and western (Loir et Cher) regions. In nurseries, " $\mathrm{Ca}$. P. fragariae" had a very low incidence in Loir et Cher, Maine et Loire, Sarthe, and Gironde. In these areas, most of the marginal chlorosis observed in the nurseries was due to the stolbur phytoplasma. These results indicate that either " $\mathrm{Ca}$. P. fragariae" is not transmitted or is poorly transmitted at the time when nursery plants are present in the field (i.e., from April to December), or that the vector is not present in the areas where the nurseries are. The few stolburinfected plants found in production fields could be explained by the efficient removal of the stolbur-infected nursery plants performed by the nursery attendants before harvesting. Indeed, affected plants are prominent in nursery rows with stunting and reddening of old leaves (23). In addition, those escaping eradication have poor root systems and do not grow well when planted in production fields, where they are immediately replaced. Thus, stolbur-infected plants that are found in production fields are likely the result of natural transmission by the major planthopper vector of the stolbur phytoplasma, Hyalesthes obsoletus, a polyphagous insect known to be present to transmit the phytoplasma from July to middle August (4).

To date, " $\mathrm{Ca}$. P. fragariae" has been reported only in France. A strawberry-associated bacteriumlike pathogen was described in Australia more than 20 years ago when no taxonomic characterization methods were available (10). However, the symptoms (interveinal chlorosis) associated with this pathogen were different from those induced by " $C a$. P. fragariae." The natural vector of the Australian bacterium was not identified.

In the present paper, we show that natural transmission of " $\mathrm{Ca}$. P. fragariae" to strawberry plants occurred in production fields after summer planting and during the spring, when infectious Cixius wagneri planthoppers are present. We experimentally demonstrated efficient transmission of " $C a$. P. fragariae" by this planthopper to strawberry plants.

Planthoppers are vectors of phloem-restricted bacterial pathogens such as phytoplasmas $(4,29)$, but had not been reported as vector of proteobacteria until recently. Indeed, the cixiid planthopper Pentastiridius beieri has been shown to be the vector for the bacterium associated with the syndrome "basses richesses" (SBR) of sugar beet in Burgundy (eastern France) (6). Interestingly, this bacterium is phylogenetically very closely related to "Ca. P. fragariae." Furthermore, P. beieri can also transmit the stolbur phytoplasma to sugar beet in which the phytoplasma produces symptoms indistinguishable from those of SBR (7). Whether marginal chlorosis of strawberry and SBR of sugar beet, two diseases that developed simultaneously in two areas of France, are caused by the same bacterium will be investigated.

Finding infected Cixius wagneri in strawberry fields in the spring and fall of 2001, the two periods during which transmission by an aerial vector was demonstrated, supports the conclusion that Cixius wagneri is the major vector of " $\mathrm{Ca}$. P. fragariae." However, because this insect had been very rarely captured from 1994 to 2000 during an extensive homopteran insect inventory of strawberry fields (3), the implication of other vectors cannot be ruled out. P. beieri was never captured in strawberry fields. Its ability to transmit "Ca. P. fragariae" to strawberry will be determined in future studies as well as the ability of Cixius wagneri to transmit the bacterium of SBR to sugar beet.

Little is known on the biology of Cixius wagneri, except that it has been reported to be present on oak forest trees. Confirmation of its ecological niche will allow us to determine the overwintering stage and to identify plant reservoirs of " $\mathrm{Ca}$. P. fragariae." Preliminary testing of weeds around strawberry fields did not reveal infected plants (J. L. Danet, unpublished data), and the main plant source of " $\mathrm{Ca}$. P. fragariae" has yet to be identified. Cixius wagneri mating could be observed when insects were caged on strawberry plants, but the number of insect generations per year remains to be determined. However, the presence of adults from spring to fall suggests several insect generations per year. An intensive survey for this insect and establishment of experimental rearing conditions are needed to determine whether Cixius wagneri is able to reproduce on strawberry plants. Answering these questions will help us to control the spread of strawberry marginal chlorosis and to understand how it emerges.

No conclusions could be drawn from the experiments meant to determine the ability of whiteflies to transmit " $\mathrm{Ca}$. P. fragariae." Indeed, whiteflies collected in a strawberry farm in which a high incidence of " $\mathrm{Ca}$. P. fragariae" occurred were neither infected nor infectious in our experiment, confirming previous results (3). The natural spread of the disease observed in the experimental tunnels in which whiteflies had been introduced was unfortunately impaired by the undesired presence of the planthopper vector in the tunnels in 2001, hence the failure to keep the control tunnels free of disease. During the last year of the experiment, the disease spread at a higher rate in the tunnel in which no whiteflies were delivered. Therefore, even though whiteflies acquired and multiplied " $\mathrm{Ca}$. P. fragariae" under greenhouse conditions and a clear increase of the disease was observed in the tunnel containing whiteflies after the first year, we could not demonstrate that they transmitted the bacterium. Thus, the involvement of whiteflies in the natural spread of " $\mathrm{Ca}$. P. fragariae" remains unknown.

\section{ACKNOWLEDGMENTS}

This work was supported by a grant from EU-Région Aquitaine funds. We acknowledge CIREF (Centre Inter-régional de Recherche et Expérimentation de la Fraise) for technically supporting transmission experiments in large tunnel conditions and CIREF and DRAF (Regional Agriculture Services) for grant support of X. Foissac. We thank the French Plant Protection Services for providing some of the plants tested during this study, J. Bonfils and T. Bourgoin (Museum National d'Histoire Naturelle, Paris) for their help in planthopper identifications, J.-B. Reynaud and P. Bonnet for excellent technical support, and J. S. Semancik (University of California, Riverside) for critical review of the manuscript.

\section{LITERATURE CITED}

1. Andersen, M. T., Longmore, J., Liefting, L. W., Wood, G. A., Sutherland, P. W., Beck, D. L., and Forster, R. L. S. 1998. Phormium yellow leaf phytoplasma is associated with strawberry lethal yellows disease in New Zealand. Plant Dis. 82:606-609.

2. Clark, M. F., Barbara, D. J., and Davies, D. L. 1983. Production and characteristics of antisera to Spiroplasma citri and clover phyllodyassociated antigens derived from plants. Ann. Appl. Biol. 103:251-259.

3. Foissac, X., Danet, J. L., Zreik, L., Gandar, J., Nourrisseau, J. G., Bové, J. M., and Garnier, M. 2000. Cloning of SpoT gene of "Candidatus Phlomobacter fragariae" and development of a PCR-RFLP assay for the detection of the bacterium in insects. Appl. Environ. Microbiol. 66:34743480.

4. Fos, A., Danet, J. L., Zreik, L., Garnier, M., and Bové, J. M. 1992. Use of a monoclonal antibody to detect the stolbur mycoplasmalike organism in plants and insects and to identify a vector in France. Plant Dis. 76:1092-1096.

5. Garnier, M., Martin-Gros, G., Iskra, M. L., Zreik, L., Gandar, J., Fos, A., and Bové, J. M. 1990. Monoclonal antibodies against the MLOs associated with tomato stolbur and clover phyllody. Pages 263-269 in: 
Proc. Int. Organ. Mycoplasmology, 7th. Zentbl. Bakteriol. Suppl. 20.

6. Gatineau, F., Jacob, N., Vautrin, S., Larrue, J., Lherminier, J., RichardMolard, M., and Boudon-Padieu, E. 2002. Association with the syndrome "basses richesses" of sugar beet of a phytoplasma and a bacterium-like organism transmitted by a Pentastiridius sp. Phytopathology 92:384-392.

7. Gatineau, F., Larrue, J., Clair, D., Lorton, F., Richard-Molard, M., and Boudon-Padieu, E. 2001. A new natural planthopper vector of stolbur in the genus Pentastiridius (Hemiptera: Cixiidae). Eur. J. Plant Pathol. 107:263-271.

8. Gawel, N. J., and Jarret, R. L. 1991. A modified CTAB DNA extraction procedure for Musa and Ipomea. Plant Mol. Biol. Rep. 9:262-266.

9. Giustina, D. 1989. Homoptères Cicadellidae. Compléments aux ouvrages d' Henri Ribaut, Faune de France 73, Fédération Française des Sociétés de Sciences Naturelles et Office Central de Faunistique, vol. 3. INRA, Paris.

10. Greber, R. S., and Gowanlock, D. H. 1979. Rickettsia-like and mycoplasma-like organisms associated with two yellows-type diseases of strawberries in Queensland. Austr. J. Agric. Res. 30:1101-1109.

11. Harrison, N. A., Legard, D. E., DiBonito, R., and Richardson, P. A. 1997. Detection and differentiation of phytoplasmas associated with diseases of strawberry in Florida. Plant Dis. 81:230.

12. Honetslegrova, J. F., Vibio, M., and Bertaccini, A. 1996. Electron microscopy and molecular identification of phytoplasmas associated with strawberry green petals in the Czech Republic. Eur. J. Plant Pathol. 102:831-835.

13. Jomantiene, R., Davis, R. E., Dally, E. L., and Maas, J. L. 1998. The distinctive morphology of 'Fragaria multicipita' is due to phytoplasma. HortScience 33:1069-1072.

14. Jomantiene, R., Davis, R. E., Maas, J. L., and Dally, E. L. 1998. Classification of new phytoplasmas associated with diseases of strawberry in Florida, based on analysis of $16 \mathrm{~S}$ rRNA and ribosomal protein gene operon sequences. Int. J. Syst. Bacteriol. 48:269-277.

15. Jomantiene, R., Maas, J. L., Dally, E. L., and Davis, R. E. 1999. First report of clover proliferation phytoplasma in strawberry. Plant Dis. 83:967.

16. Jomantiene, R., Maas, J. L., Dally, E. L., and Davis, R. E. 1999. First report of clover yellow edge and of STRAWB2 phytoplasmas in Maryland. Plant Dis. 83:1072.

17. Jomantiene, R., Maas, J. L., Davis, R. E., and Dally, E. L. 2001. Molecular identification and classification of a phytoplasma associated with phyllody of strawberry fruit in Maryland. Plant Dis. 85:335.

18. Jomantiene, R., Maas, J. L., Takeda, F., and Davis, R. E. 2002. Molecular identification and classification of strawberry phylloid fruit phytoplasma in group 16SrI, new subgroup R. Plant Dis. 86:920.

19. Lee, I. M., Davis, R. E., and Gundersen-Rindal, D. E. 2000. Phytoplasma: Phytopathogenic mollicutes. Annu. Rev. Microbiol. 54:221-255.

20. Liu, T., and Oetting, R. 1993. Morphological comparisons of three species of whiteflies (Homoptera). Ga. Agric. Exp. Stn. Res. Bull. 412.

21. Maas, J. L. 1998. Compendium of Strawberry Diseases. 2nd ed. The American Phytopathological Society, St. Paul, MN.

22. Maixner, M., Ahrens, U., and Seemüller, E. 1995. Detection of the German grapevine yellows (Vergilbungskrankheit) MLO in grapevine, alternative hosts and a vector by a specific PCR procedure. Eur. J. Plant Pathol. 101:241-250.

23. Nourrisseau, J. G., Lansac, M., and Garnier, M. 1993. Marginal chlorosis, a new disease of strawberries associated with a bacteriumlike organism. Plant Dis. 77:1055-1059.

24. Padovan, A., Gibb, K., and Persley, D. 2000. Association of 'Candidatus Phytoplasma australiense' with green petal and lethal yellows diseases in strawberry. Plant Pathol. 49:362-369.

25. Ribaut, H. 1936. Homoptères Auchénorrhynques I (Typhlocybidae), Faune de France 31, Fédération Française des Sociétés de Sciences Naturelles et Office Central de Faunistique, Paul Lechevallier, Paris.

26. Ribaut, H. 1952. Homoptères Auchénorrhynques II (Jassidae) Faune de France 57, Fédération Française des Sociétés de Sciences Naturelles et Office Central de Faunistique, Paul Lechevallier, Paris.

27. Seemüller, E., Marcone, C., Lauer, U., Ragozzino, A., and Göschl, M. 1998. Current status of molecular classification of the phytoplasmas. J. Plant Pathol. 80:3-26.

28. Smart, C. D., Schneider, B., Blomquist, C. L., Guerra, L. J., Harrison, N. A., Ahrens, U., Lorentz, K. H., Seemüller, E., and Kirkpatrick, B. C. 1996. Phytoplasma-specific PCR primers based on sequences of the 16S23S rRNA spacer regions. Appl. Environ. Microbiol. 62:2988-2993.

29. Tsai, J. H. 1979. Vector transmission of mycoplasmal agents of plant disease. Pages 265-307 in: The Mycoplasmas, vol. 3. R. F. Whitcomb and J. G. Tully, eds. Academic Press, New York.

30. Zreik, L., Bové, J. M., and Garnier, M. 1998. Phylogenetic characterization of the bacterium-like organism associated with marginal chlorosis of strawberry and proposition of a Candidatus taxon for the organism "Candidatus Phlomobacter fragariae." Int. J. Syst. Bacteriol. 48:257-261. 